\title{
INVESTIGATION OF SEXUAL LIFE QUALITY AND RELATED FACTORS IN THE POSTPARTUM PERIOD
}

\section{Postpartum Dönemde Cinsel Yaşam Kalitesi ve İlişkili Faktörlerin İncelenmesi}

\author{
Hafize DA $\breve{G} T U ̈ Z M E N^{1}$ (i) Emel EGE ${ }^{2}$ (1) \\ ${ }^{1}$ The Konya Chamber of Commerce Karatay University, School of Health Sciences, Konya, Turkey \\ ${ }^{2}$ Necmettin Erbakan University, Faculty of Nursing, Konya, Turkey
}

\begin{tabular}{ll}
\hline Geliş Tarihi / Received: 29.12.2020 & Kabul Tarihi / Accepted: 30.04 .2021 \\
\hline
\end{tabular}

\begin{abstract}
This research is a descriptive study to examine sexual quality of life and associated factors during the postpartum period. The sample of the study consisted of 390 postpartum women who admitted to the Pediatric Polyclinics of a Faculty of Medicine in Konya and met the inclusion criteria. A questionnaire form prepared by the researchers and the Sexual Quality of Life Scale (SQOL-F) Female form were used to collect the data. Kruskal Wallis test, Mann Whitney U test, regression analysis were used to evaluate the data. The mean score of women SLQO-F was found as $85.23 \pm 18.43$ and was found to be above the average. In this study, age of the woman, education level, education level of the spouse, employment status, duration of marriage, amount of income, number of pregnancies, breastfeeding status, planning of the last pregnancy, type of delivery and the frequency of sexual intercourse were determined to have an effect on SQL-F score $(p<0.05)$. The postpartum period negatively affects the quality of sexual life. Health professionals may be advised to plan counseling services for all women before, during and after pregnancy to maintain and improve the quality of sexual life.
\end{abstract}

Keywords: Postpartum period, Postpartum sexual life, Sexual quality of life.

\section{ÖZ}

Bu araştırma, postpartum dönemde cinsel yaşam kalitesi ve ilişkili faktörleri incelemek için yapılmış tanımlayıcı nitelikte bir çalışmadır. Araştırma örneklemini Konya ilinde bulunan bir tıp fakültesinin Pediatri Polikliniklerine başvuran ve katılma kriterlerini taşıyan 390 kadın oluşturdu. Verilerin toplanmasında araştırmacılar tarafından hazırlanan bir anket formu ve Cinsel Yaşam Kalitesi Ölçeği-Kadın (CYKÖ-K) formu kullanıldı. Verilerin değerlendirilmesinde Kruskal Wallis testi, Mann Whitney U testi ve regresyon analizi kullanıldı. Kadınların CYKÖ-K puan ortalamasının $85.23 \pm 18.43$ olduğu ve ortalamanın üzerinde olduğu bulundu. Bu çalışmada kadının yaşı, öğrenim durumu, eşinin öğrenim durumu, çalışma durumu, evlilik süresi, gelir miktarı, gebelik sayısı, emzirme durumu, son gebeliğin planlı olması, doğum şekli ve cinsel ilişkiye girme sıklı̆̆ gibi özelliklerin CYKÖ-K puanı üzerinde etkili olduğu belirlendi $(\mathrm{p}<0.05)$. Postpartum dönem cinsel yaşam kalitesini olumsuz yönde etkilemektedir. Sağlık profesyonellerinin, cinsel yaşam kalitesinin korunması ve geliştirilmesi için gebelik öncesi, gebelikte ve doğum sonrası dönemde tüm kadınlara yönelik danışmanlık hizmeti planlamaları önerilebilir.

Anahtar kelimeler: Cinsel yaşam kalitesi, Postpartum cinsel yaşam, Postpartum dönem. 


\section{INTRODUCTION}

According to the World Health Organization (WHO), "sexuality is a combination of physical, emotional, intellectual and social aspects that has an enriching effect on personality, communication, and love". Also, it is stated that sexuality is a situation that has psychosocial, economic, cultural, legal, political, religious, and historical dimensions (WHO, 2010). Sexuality, which plays a significant role in women's lives, is a phenomenon that both affects society and gets affected by society (Koç \& Oskay, 2016). The developmental processes which start with menarche and covers pregnancy and postpartum period affect sexual life (Kurtçu \& Gölbaş1, 2014; Tuğut \& Gölbaş1, 2010).

The physical, hormonal, psychological, and sociocultural changes that are experienced in the postpartum period which is a part of the life cycle of females affect the quality of the sex life of couples (Abdool, Thakar, \& Sultan, 2009). WHO has defined quality of life as "the individuals' perception of their lives in their cultural context and the value systems, goals, standards and interests in their lives" (WHO, 1998). The postpartum period is a period characterized by social, emotional, and physical changes for the female who has just become a mother. Due to these changes, the woman who has just become a mother experiences anxiety about baby care as well as taking care of herself, and she needs information in this regard. During this period, the woman adapts to parenting roles, and if she manages to be successful in baby care, her quality of life is affected positively. However, feelings that a mother experiences, such as stress, loss of self-control, anxiety, lack of performance, etc. have a negative effect on the quality of life (Altuntug \& Ege, 2012). When the studies conducted are examined, in their study, Serati et al. determined that the delay in the postpartum sexual activity was associated with dyspareunia problem and breastfeeding (Serati et al., 2010). Acele and Karaçam stated in their study that $47.4 \%$ of women in the postpartum period were not pleased with their physical appearances (Acele \& Karaçam, 2011). According to the study conducted by Rathfisch et al., it was stated that sexual function is negatively affected as a result of episiotomy and spontaneous perineal tears, causing a decrease in satisfaction with sex life (Rathfisch et al., 2010).

Sex life during the postpartum period could be affected by physical and socio-cultural factors. It is known that advanced maternal age, a high number of births, labor interventions and breastfeeding have negative effects on the postpartum sex life of women (Karaçam, 2008; Klein et al., 2009). Therefore, it is very important to be aware of the features of the postpartum period when the sexuality of women is highly affected and sexual problems are 
often experienced. Many women and health professionals are unwilling and shy when it comes to talking about sexuality, while they are willing to discuss issues experienced during this period such as breastfeeding, baby care, etc. Health professionals need to have adequate knowledge regarding the issues experienced in this period and solutions to them in order to be able to provide a good consultancy service on sexuality and to guide the individuals for identifying and treating the sexual problems. The study was conducted in order to determine the quality of postpartum sex life and related factors.

\section{MATERIAL AND METHOD}

The population of this descriptive research was composed of women who applied to Pediatric Polyclinic of a medical faculty hospital in Konya city center and who met the inclusion criteria for the study. A table 'predicting the rate in a society with certain accuracy' (Lemeshow S, Hosmer DW, Klar J and Lwanga SK. The adequacy of the sample size in health research. Translated by: S Oğuz Kayaalp p: 143) was used to determine the sample of the study. The rate (54\%) reported by a study (Şahin, 2009) was utilized as a finding related to the prevalence of the phenomenon examined in the study (decrease in sexual desire) in society. The reported rate was evaluated as $55 \%$ in the table and $95 \%$ confidence level and $5 \%$ relative accuracy were taken into account, and the sample size reported in the table was found to be 380. In order to avoid any loss of subject, 20 individuals were included in the substitute sample. After surveys with data loss were removed, the study was completed with 390 women who were in the postpartum period. It was determined by regression analysis that seven independent variables were effective on women's sexual life quality score (R2 = .59). According to the post hoc power analysis performed with the G-Power program (3.1.9.2), the effect size $\mathrm{f}=1.17$ (large / large) and power 1.00 (100\%) values were found, so they showed that the number of subjects in the sample was sufficient. The selection of the sample was made through random sampling, one of the improbable sampling methods. The selection of the sample was made through random sampling, one of the improbable sampling methods.

\section{Data Collection}

The data were collected by the researcher using face-to-face interview method between 3-17 July 2018. A questionnaire form developed by the researcher using the literature and the Sexual Quality of Life-Female (SQOL-F) scale were used in the collection of data. It was prepared by the researcher using the information in the literature and similar research (Barrett et al., 2000; Basson, Brotto, Laan, Redmond, \& Utian, 2005). The form includes 45 questions 
about the individual's socio-demographic characteristics, obstetric characteristics, postpartum characteristics, and knowledge of the sexual quality of life.

\section{Sexual Quality of Life Scale-Female}

It is a reliable and valid scale confirmed by Symonds et al. (Symonds, Boolell, \& Quirk, 2005). Turkish validity and reliability study of the scale has been conducted by Tuğut and Gölbaş1 in 2010 (Tuğut \& Gölbaş1, 2010). The scale may be applied to all adult women; however, validity and reliability study of the original scale has been conducted on women between 18 and 65 years of age. The scale is easily applicable six-Likert type including 18 items which may be answered by individuals. Each question is expected to be answered by considering the sexual life of the individual within four weeks (Tuğut \& Gölbaşı, 2010). Each question is scored between 1 and 6 for scoring. The scoring system will be as follows; 1=Fully agree; 2=Widely agree; 3= Partially agree; 4=Partially Disagree; Widely disagree; 6=Fully disagree. The score that may be obtained from the scale vary between 18 and 108 . Before calculation of the total score, scores of questions 1, 5, 9, 13, and 18 should be reversed. For conversion of total scale score to 100; the formula (Scale raw score-18) *100/90) should be used. For instance, an individual with raw score of 63 obtained from the scale has the converted scale score of $(63-18) * 100 / 90=50$. Higher score obtained from the scale indicates a well sexual quality of life. The Cronbach $\alpha$ reliability coefficient was determined as 0.83. (Tuğut \& Gölbaş1, 2010). The Cronbach alpha value of the Sexual Quality of Life Scale- Female (SQOL-F) was found .90 in this study.

\section{Evaluation of Data}

Statistical analysis of the data obtained in the research was conducted with the SPSS program. In data evaluation, descriptive statistics such as numbers, percentage values, means, and standard deviation were used. The compliance of the scale scores as the numerical variable with normal distribution was evaluated with Skewness and Kurtosis. It was determined that they displayed normal distribution (between -2 and +2) according to Skewness (-1.55) and Kurtosis (1.77) values. In comparing the mean score of the Sexual Quality of Life-Female (SQOL-F) scale according to women's identifying characteristics, obstetric characteristics, postpartum period characteristics and sex life characteristics, t-test and Mann Whitney $U$ test (if $n<30$ ) were used in the independent variables based on the number of samples in groups in binary-group variables. In variables with three or more groups, one-way analysis of variance (further analysis Tukey HSD (honestly significant difference) and Kruskal Wallis test (further analysis Mann Whitney U test with Bonferroni 
correction and Tukey test) were used in independent groups based on the number of samples in groups. The independent variables that had an effect on the Sexual Quality of Life-Female (SQOL-F) scale scores in the primary analysis were evaluated by multiple regression (backward method) analysis. The significance level was considered to be $\mathrm{p}<.05$.

\section{Limitations}

The results of this research are only valid for the subject group of this research, and they cannot be generalized for the society.

\section{Ethical Considerations}

In order to conduct this research, ethics committee approval (dated 01.06.2018, numbered 2018/1404) from Necmettin Erbakan University Non-Interventional Clinical Research Ethics Committee and permission from the institution where the research would be conducted were obtained. In order to conduct the research in the relevant institution, permission (dated 12.06.2018, numbered 14567952-900-E.38464) from the Department of Pediatrics of Meram Faculty of Medicine in Necmettin Erbakan University was obtained. In order to use the Sexual Quality of Life-Female (SQOL-F) scale, permission was obtained from Nilüfer Tugut and Zehra Gölbaşı via e-mail. The participants were informed about the study, and their verbal consent was obtained.

\section{RESULT}

The mean SQOL-F score of the women in the research was found to be $85.23 \pm 18.43$. The mean age of women participating in the study was determined as $27.38 \pm 4.96 .58 .7 \%$ of women had primary school education, $29.7 \%$ of them were high school graduates, and $45 \%$ had a university degree, $80.3 \%$ of them were unemployed, $19.7 \%$ of them were employed. Regarding the duration of the marriage, $53.8 \%$ were found to be married for 5 years and below, 28.2\% between 6-10 years and $17.9 \% 11$ years and above.

Table 1. Comparison of the Sexual Quality of Life-Female (SQOL-F) Scale Mean Score by Identifying Characteristics (n: 390)

\begin{tabular}{llllll}
\hline Characteristics & $\mathrm{S}$ & $\%$ & $\overline{\mathbf{X}} \pm$ SD & Test & $\begin{array}{l}\text { p } \\
\text { (difference) }\end{array}$ \\
\hline $\begin{array}{l}\text { Mother's age } \\
\leq 24 \text { years }^{\text {a }}\end{array}$ & 131 & 33.6 & $92.36 \pm 10.77$ & F: 73.880 & .000 \\
$\begin{array}{l}\text { 25-29 years } \\
\geq 30 \text { years }^{\text {b }}\end{array}$ & 134 & 34.4 & $91.38 \pm 12.75$ & & $(\mathrm{a}>\mathrm{b})$ \\
\hline Educational status $^{\text {Primary School }}{ }^{\text {a }}$ & 125 & 32.0 & $71.16 \pm 21.79$ & & .000 \\
High School $^{\text {b }}$ & 229 & 58.7 & $79.32 \pm 20.67$ & F: 27.756 & $(\mathrm{a}<\mathrm{b})$
\end{tabular}




\begin{tabular}{|c|c|c|c|c|c|}
\hline University $^{\mathrm{b}}$ & 45 & 11.6 & $95.19 \pm 8.12$ & & \\
\hline \multicolumn{6}{|l|}{ Employment status } \\
\hline Unemployed & 313 & 80.3 & $82.89 \pm 19.30$ & $\mathrm{t}: 5.229$ & .000 \\
\hline Employed & 77 & 19.7 & $94.75 \pm 9.68$ & & \\
\hline \multicolumn{6}{|l|}{ Age of the spouse } \\
\hline$\leq 24$ years ${ }^{a}$ & 55 & 14.1 & $91.86 \pm 11.31$ & $F: 45.605$ & .000 \\
\hline $25-29$ years $^{\text {a }}$ & 148 & 37.9 & $93.33 \pm 10.72$ & & $(a>b)$ \\
\hline$\geq 30$ years $^{b}$ & 187 & 48.0 & $76.87 \pm 21.13$ & & \\
\hline \multicolumn{6}{|l|}{$\begin{array}{l}\text { Educational status of the } \\
\text { spouse }\end{array}$} \\
\hline Primary School a & 189 & 48.5 & $77.93 \pm 21.47$ & F: 33.953 & .000 \\
\hline High School b & 108 & 27.7 & $91.19 \pm 12.41$ & & $(\mathrm{a}<\mathrm{b})$ \\
\hline University $^{\mathrm{b}}$ & 93 & 23.8 & $93.13 \pm 9.99$ & & \\
\hline \multicolumn{6}{|l|}{ Duration of marriage } \\
\hline$\leq 5$ years $^{\text {a }}$ & 210 & 53.8 & $92.82 \pm 10.56$ & F: 80.637 & .000 \\
\hline $6-10$ years $^{b}$ & 110 & 28.2 & $83.05 \pm 17.33$ & & $(\mathrm{a}>\mathrm{b}>\mathrm{c})$ \\
\hline$\geq 11$ years $^{c}$ & 70 & 18.0 & $65.87 \pm 23.21$ & & \\
\hline \multicolumn{6}{|l|}{ Place of residence } \\
\hline Town/county/village $^{\text {a }}$ & 63 & 16.2 & $79.91 \pm 21.59$ & F: 5.112 & .006 \\
\hline District center & 130 & 33.3 & $83.82 \pm 19.40$ & & $(\mathrm{a}<\mathrm{b})$ \\
\hline Provincial center ${ }^{\mathrm{b}}$ & 197 & 50.5 & $87.86 \pm 16.17$ & & \\
\hline \multicolumn{6}{|l|}{ Family Type } \\
\hline Extended family & 106 & 27.2 & $78.32 \pm 22.39$ & $\mathrm{t}: 4.639$ & \\
\hline Nuclear family & 284 & 72.8 & $87.81 \pm 16.00$ & & .000 \\
\hline \multicolumn{6}{|l|}{ Income level } \\
\hline Minimum wage and below & 118 & 30.3 & $82.24 \pm 19.65$ & $\mathrm{t}: 2.118$ & .035 \\
\hline Above minimum wage & 272 & 69.7 & $86.52 \pm 17.75$ & & \\
\hline
\end{tabular}

The comparison of the mean SQOL-F scores according to the identifying characteristics of women is given in Table 1. When the educational status was examined, it was found that primary school graduate women had a low STI score. ( $<.05$, Table 1$)$. The comparison of the mean SQL-F scores according to the identifying characteristics of women was shown in Table 1. When the mean SQL-F score of women was compared by age, it was determined that women aged 30 and over 30 had a low mean score $(\mathrm{p}<.05$, Table 1$)$. When the educational status was examined, it was found that primary school graduate women had low SQL-F scores. ( $<<.05$, Table 1 ). Considering the employment status of women, it was found that the average SQL-F score of employed women was higher than those who were unemployed (p $<.001$, Table 1). Examining the average score according to the age of their spouse, it was determined that women whose spouse's age was 30 years old and over 30 had a low SQL-F score ( $<$ <.05 Table 1). Considering the education status of their spouses, the scores of women whose spouses were primary school graduates were found low ( $<<.05$ Table 1). Considering the mean scores according to the duration of marriage, the average score of those whose marriage duration was five years or less was found high $(\mathrm{p}<.05)$. When the places where 
women live were examined, it was determined that the average score of women living in the city center was high ( $\mathrm{p}<.05$ Table 1 ). Considering the family type, the average score of women having nuclear families was found higher than those having extended families (p $<.001$, Table 1). When the income level of women was examined, it was found that the average score $(86.52 \pm 17.75)$ of those whose income was above the minimum wage was higher than those whose income was minimum wage or below it $(\mathrm{p}<.05$, Table 1$)$.

Table 2: Comparison of the Mean Sexual Quality of Life (SQOL-F) Scale Scores According to Women's Pregnancy and Postpartum Period Characteristics (S: 390)

\begin{tabular}{|c|c|c|c|c|c|}
\hline Characteristics & $\mathrm{S}$ & $\%$ & $\overline{\mathbf{X}} \pm \mathrm{SD}$ & Test & $\begin{array}{l}\mathrm{p} \\
\text { (difference) }\end{array}$ \\
\hline \multicolumn{6}{|l|}{ Number of Pregnancies } \\
\hline Multipara & 286 & 73.3 & $82.14 \pm 19.87$ & $\mathrm{t}: 5.698$ & .000 \\
\hline Primipara & 104 & 26.7 & $93.71 \pm 9.52$ & & \\
\hline \multicolumn{6}{|l|}{$\begin{array}{l}\text { Number of Surviving } \\
\text { Children }\end{array}$} \\
\hline 1 child $^{\text {a }}$ & 159 & 40.8 & $93.40 \pm 10.27$ & F: 69.702 & .000 \\
\hline 2 children ${ }^{\mathrm{b}}$ & 112 & 28.7 & $88.45 \pm 14.11$ & & $(a>b>c)$ \\
\hline$\geq 3$ children $^{c}$ & 119 & 30.5 & $71.27 \pm 22.23$ & & \\
\hline \multicolumn{6}{|l|}{ Planned pregnancy } \\
\hline Unplanned pregnancy & 159 & 40.8 & $80.14 \pm 21.08$ & $\mathrm{t}: 4.642$ & .000 \\
\hline Planned Pregnancy & 231 & 59.2 & $88.73 \pm 15.45$ & & \\
\hline \multicolumn{6}{|l|}{ Delivery Method } \\
\hline Cesarean section & 190 & 48.7 & $80.92 \pm 20.17$ & $\mathrm{t}: 4.612$ & .000 \\
\hline Normal delivery & 200 & 51.3 & $89.32 \pm 15.58$ & & \\
\hline \multicolumn{6}{|l|}{ Breastfeeding } \\
\hline Not breastfeeding & 30 & 7.7 & $73.11 \pm 23.26$ & $\mathrm{t}: 3.814$ & .000 \\
\hline Breastfeeding & 360 & 92.3 & $86.24 \pm 17.63$ & & \\
\hline $\begin{array}{l}\text { Physical } \\
\text { Appearance } \\
\text { Evaluation }\end{array}$ & & & & & \\
\hline Poor $^{\mathrm{a}}$ & 30 & 7.7 & $70.44 \pm 21.95$ & $\mathrm{~F}: 19.084$ & .000 \\
\hline Medium b & 107 & 27.4 & $80.87 \pm 21.38$ & & $(\mathrm{a}<\mathrm{b}<\mathrm{c})$ \\
\hline Good $^{\mathrm{c}}$ & 253 & 64.9 & $88.82 \pm 15.14$ & & \\
\hline
\end{tabular}

t: t-test in independent groups, sd: 388, F: Variance analysis in independent groups, inter-group/intra-group/total, sd:2/387/389.

When the mean SQOL-F scale score was examined according to women's pregnancy and postpartum period characteristics, it was determined that the mean SQOL-F scale score of primipara women was higher than that of multipara women $(p<.05$, Table 2$)$. When the number of children was examined, it was determined that the mean SQOL-F score of women with one child was higher $(\mathrm{p}<.05)$. The mean SQOL-F scale score was found to be high in planned pregnancies $(\mathrm{p}<.001$, Table 2$)$. The mean SQOL-F scale score of women who gave normal birth was determined to be higher than those who gave birth by cesarean section 
( $<<.001$, Table 2). It was determined that the mean SQOL-F scale score was high in women who breastfed $(\mathrm{p}<.001$, Table 2$)$. When SQOL-F scale scores were examined according to women's evaluation of their physical appearance after birth, it was determined that the mean score of women who evaluated their physical appearance to be good was high $(\mathrm{p}<.05)$

Table 3: Comparison of the Mean Sexual Quality of Life (SQOL-F) Scale Score According to Women's Sexual Life History (S: 390)

\begin{tabular}{|c|c|c|c|c|c|}
\hline $\begin{array}{l}\text { Sexual Life History } \\
\text { Characteristics }\end{array}$ & $\mathrm{S}$ & $\%$ & $\overline{\mathbf{x}} \pm \mathrm{SD}$ & Test & $\begin{array}{l}\mathrm{p} \\
\text { (difference) }\end{array}$ \\
\hline \multicolumn{6}{|l|}{$\begin{array}{l}\text { Frequency of sexual } \\
\text { intercourse } \\
\text { (number/month) }\end{array}$} \\
\hline$\leq 4$ & 196 & 50.3 & $78.05 \pm 20.81$ & $\mathrm{t}: 8.395$ & .000 \\
\hline$\geq 5$ & 194 & 49.7 & $92.48 \pm 11.90$ & & \\
\hline \multicolumn{6}{|c|}{$\begin{array}{l}\text { Evaluation of postpartum } \\
\text { sexual life }\end{array}$} \\
\hline Poor ${ }^{a}$ & 20 & 5.1 & $43.67 \pm 14.30$ & KW:155.194 & .000 \\
\hline Medium ${ }^{b}$ & 155 & 39.8 & $78.25 \pm 17.92$ & & $(\mathrm{a}<\mathrm{b}<\mathrm{c})$ \\
\hline Good $^{\mathrm{c}}$ & 215 & 55.1 & $94.12 \pm 9.57$ & & \\
\hline \multicolumn{6}{|c|}{$\begin{array}{l}\text { Evaluation of Postpartum } \\
\text { Communication with the } \\
\text { Spouse }\end{array}$} \\
\hline Unsatisfied & 54 & 13.8 & $62.78 \pm 21.81$ & t: 8.463 & .000 \\
\hline Satisfied & 336 & 86.2 & $88.84 \pm 14.99$ & & \\
\hline \multicolumn{6}{|c|}{ Decrease in sexual desire } \\
\hline Yes & 37 & 9.5 & $78.77 \pm 21.98$ & $\mathrm{t}: 2.253$ & .025 \\
\hline No & 353 & 90.5 & $85.90 \pm 17.91$ & & \\
\hline \multicolumn{6}{|l|}{ Painful Orgasm } \\
\hline Yes & 15 & 3.8 & $74.89 \pm 24.45$ & $\mathrm{U}: 1784.5$ & .015 \\
\hline No & 375 & 96.2 & $85.64 \pm 18.06$ & & \\
\hline \multicolumn{6}{|c|}{ Feeling of vaginal laxity } \\
\hline Yes & 9 & 2.3 & $70.12 \pm 26.40$ & U: 1048.5 & .044 \\
\hline No & 381 & 97.7 & $85.58 \pm 18.09$ & & \\
\hline \multicolumn{6}{|l|}{$\begin{array}{l}\text { Decrease in vaginal } \\
\text { lubrication }\end{array}$} \\
\hline Yes & 9 & 2.3 & $54.94 \pm 28.41$ & $\mathrm{U}: 608.0$ & .001 \\
\hline No & 381 & 97.7 & $85.94 \pm 17.56$ & & \\
\hline \multicolumn{6}{|l|}{ Difficulty in orgasm } \\
\hline Yes & 17 & 4.4 & $73.66 \pm 27.01$ & U: 2116.5 & .019 \\
\hline No & 373 & 95.6 & $85.76 \pm 17.81$ & & \\
\hline
\end{tabular}

t: t-Test in independent groups, sd: 388; U: Mann Whitney U Test; KW: Kruskal Wallis analysis, sd:2

When the mean SQOL-F scale score was compared according to the characteristics of women's sexual life history, the mean SQOL-F scale score was found to be high in women who had sexual intercourse five times a month or more $(\mathrm{p}<.001$, Table 3$)$. The mean SQOL-F scale score was found to be high in women who stated that there was no decrease in their sexual desire $(\mathrm{p}<.05$, Table 3$)$. The mean SQOF scale score was found to be low in women who stated that they experienced painful orgasm problems during sexual intercourse $(\mathrm{p}<.05$, 
Table 3). The mean SQOL-F scale score was found to be high in women who did not experience vaginal laxity during sexual intercourse $(\mathrm{p}<.05$, Table 3$)$. It was determined that the mean SQOL-F scale score was high in women who did not experience a decrease in vaginal lubrication during sexual intercourse $(\mathrm{p}<.001$, Table 3$)$. The mean SQOL-F scale score was found to be high in women who did not have any difficulties in orgasm during sexual intercourse $(\mathrm{p}<.05$, Table 3$)$. When the mean SQOL-F scale score was examined according to women's evaluation of their postpartum sexual life, it was determined that the mean score of women who evaluated their sexual life as good was high $(\mathrm{p}<.05)$. When women's evaluation of communication with their spouse in the postpartum period was examined, it was determined that the mean SQOL-F scale score was high in women who were satisfied with communication with their spouses compared to the unsatisfied women $(\mathrm{p}<.001$, Table 3).

Table 4: The Effect of the Independent Variables on the Sexual Quality of Life-Female (SQOL-F) Scale Score: Results of Multiple Regression Analysis (S:390).

\begin{tabular}{|c|c|c|c|c|c|c|c|c|c|}
\hline \multirow{3}{*}{$\begin{array}{l}\text { Independent Variables } \\
\text { (Constant) }\end{array}$} & \multirow{3}{*}{$\begin{array}{l}\text { B } \\
18.79\end{array}$} & \multirow{3}{*}{$\begin{array}{l}\text { Std. } \\
\text { Error }\end{array}$} & \multirow{3}{*}{ ßeta } & \multirow{3}{*}{$\frac{\mathbf{t}}{1.908}$} & \multirow{3}{*}{$\begin{array}{l}\text { Sig. } \\
.057\end{array}$} & \multirow{2}{*}{\multicolumn{2}{|c|}{$\begin{array}{l}95 \% \text { Confidence } \\
\text { Interval for B }\end{array}$}} & \multirow{2}{*}{\multicolumn{2}{|c|}{$\begin{array}{l}\text { Collinearity } \\
\text { Statistics } \\
\text { Tolera } \\
\text { nce VIF }\end{array}$}} \\
\hline & & & & & & & & & \\
\hline & & & & & & -.57 & 38.15 & & \\
\hline Evaluation of Sexual Life & 11.32 & 1.42 & .37 & 7.955 & .000 & 8.52 & 14.12 & .563 & 1.776 \\
\hline Age & -9.52 & 1.61 & -.24 & 5.927 & .000 & -12.68 & -6.36 & .715 & 1.399 \\
\hline $\begin{array}{l}\text { Communication with the } \\
\text { Spouse }\end{array}$ & 11.12 & 2.13 & .21 & 5.207 & .000 & 6.92 & 15.31 & .739 & 1.352 \\
\hline $\begin{array}{l}\text { Decrease in lubrication } \\
\text { during sexual intercourse }\end{array}$ & 16.01 & 4.49 & .13 & 3.562 & .000 & 7.17 & 24.84 & .883 & 1.133 \\
\hline Decrease in sexual desire & -6.26 & 2.33 & -.10 & 2.688 & .007 & -10.84 & -1.68 & .863 & 1.158 \\
\hline $\begin{array}{l}\begin{array}{l}\text { Frequency of } \\
\text { intercourse }\end{array} \\
\end{array}$ & 3.52 & 1.43 & .10 & 2.466 & .014 & .71 & 6.33 & .788 & 1.270 \\
\hline Employment status & 4.20 & 1.66 & .09 & 2.530 & .012 & .94 & 7.46 & .922 & 1.085 \\
\hline
\end{tabular}

R: .74 Adjusted R²: .54 F: 65.79 p: .000 Durbin Watson: 1.84

Multiple regression analysis (backward method) was performed to evaluate the effect of 23 independent variables which were determined to have an effect on women's SQOL-F score in the primary analyses. The seven independent variables, which were found to be effective in multiple regression analyses performed, explained the change (variance) of the SQOL-F score of women by $54 \%$. When women's sex life evaluation status in the postpartum period was listed as poor, average, and good, the sexual quality of life of the groups improved and increased by 11.32 points. Women aged 30 and older had a decrease in their sexual quality of life score by -9.52 compared to those aged under 30 . The sexual quality of life scores of those who were satisfied with their communication with their spouse in the postpartum period 
increased by 11.12 points compared to those who were unsatisfied with their communication with their spouse. The sexual quality of life of those who did not experience a decrease in vaginal lubrication increased by 16.01 points compared to those who had a decrease in vaginal lubrication. The score of sexual quality of life of women who did not have a decrease in sexual desire decreased by -6.26 points compared to those who had a decrease in sexual desire. The sexual quality of life score of women with the frequency of five or more sexual intercourse per month increased by 3.52 points compared to those with less than five sexual intercourse per month, while the mean SQOL-F scale score of employed women increased by 4.20 points compared to unemployed women (Table 4).

\section{DISCUSSION}

The sexual function of the woman, as an important part of the quality of life, can be affected by physiological, psychological, and socio-cultural factors. Genetic, biological, cognitive, emotional, and social factors can affect the sexual function of the woman (Brotto, Chik, Ryder, Gorzalka, \& Broke, 2006; Demirci, 2012; Eshghi, Behrami, Fatehi, Etemadi, \& Ghosemi, 2012; Mert \& Özen, 2011).

The mean SQOL-F scale score of women in the research was found as $85.23 \pm 18.43$. In the study conducted by Yarali and Hacialioglu including women between the ages of 18-49, the mean SQOL-F score was found as 68.51 21.63 (Yaralı \& Hacialioğlu, 2016). Considering that the highest score that can be obtained from the scale is 108 , it can be said that the scale score of the group in the study was above the average. It can be mentioned that the results may have been influenced by the socio-demographic characteristics and regional differences of women.

When the mean SQOL-F scale score was evaluated according to the characteristics of women in pregnancy and the postpartum period, the mean SQOL-F scale score of primipara women was found to be higher compared to multipara groups, and the difference was significant (Table 2). It was determined that as the number of surviving children of women increased, the mean SQOL-F scale score decreased, and the difference between the groups was significant. The relationship between women's fertility and sexual life is one of the main elements that need to be balanced. Studies have shown that the increase in the number of children negatively affects the sexual quality of life (Yaralı \& Hacıalioğlu, 2016). There are also studies in the literature stating that the number of surviving children does not affect postpartum sexual life in women (Acele \& Karaçam, 2011; Trutnovsky, Haas, Long, \& Petru, 2006). In the postpartum period, the woman's own health, the newborn baby, as well as 
having children who are dependent on her in the house, may have caused problems in terms of sparing private time for herself and her husband.

When the scores of sexual quality of life of women were analyzed according to a planned pregnancy, it was determined that the mean SQOL-F scale score of those with planned pregnancy was significantly higher than those who had unplanned pregnancy (Table 2). Unlike the findings of the present study, in the study of Acele and Karaçam, it was found that the planned pregnancies did not affect women's sexual life in the postpartum period (Acele \& Karaçam, 2011). It was thought that the planned pregnancy providing a sense of control over the person's body and the baby being the desired one were also associated with the research result.

When the scores of sexual quality of life were examined according to the delivery method of women, it was determined that the mean SQOL-F scale score of women who gave normal vaginal birth was higher than those who gave birth by cesarean section, and the difference was found to be significant (Table 2). In the study conducted by Güngör et al. (2007) which covering primipara women, it was found that the prevalence of sexual dissatisfaction in women who gave birth by cesarean-section was $4.4 \%$, while it was $14.4 \%$ in those with normal vaginal birth, but the difference was not found statistically significant (Güngör, Başer, Ceyhan, Karaşahin, \& Acikel, 2007). Satisfaction with sexual intercourse with the spouse was found to be significant in those who gave birth by cesarean section (Güngör et al., 2007). When the women who gave birth by cesarean section and the women who give a normal birth were compared in the literature, it was seen that there were also studies which indicated that the rate of pelvic floor dysfunction such as urinary and fecal incontinence was high, and sexuality was affected negatively accordingly. (Brubaker et al., 2008). Changes in genital organs and sexual problems experienced vary depending on the method of birth, whether the birth necessitated intervention and the degree of trauma in the perineum. In the study conducted by Lurie et al. in 2013, when the sexual functions of women who decided to give birth by themselves were compared, the difference between women who gave birth by vaginal and cesarean section was not found significant (Lurie et al., 2013). In other studies, it was found that there was no significant relationship among the delivery type and experiencing sexual problems, sexual role, sexual desire, perineal muscle strength and dyspnoea. There are also other studies showing that there was no significant relationship in terms of experiencing sexual problems, sexual role, sexual willingness, the strength of perineal muscles, and dyspareunia (Barrett et al., 2000; Baytur et al., 2005; Wang, Xu, Yao, \& Zhou, 2003). When the status of the delivery method of birth is evaluated, the process of 
postpartum recovery occurs faster in women who gave a normal birth. Moreover, a lower mean SQOL-F scale score in the group with a cesarean section can be explained by the anxiety of being harmed during sexual activity due to having undergone surgery.

In the postpartum period, the prolactin hormone is activated, and the lactation process is initiated. This situation is stated to be a factor that adversely affects the sexual life of women who are breastfeeding (Karaçam, 2008; Serati et al., 2010; Signorello, Harlow, Chekos, \& Repke, 2001). When the scores of sexual quality of life were examined according to the status of breastfeeding, it was determined that the mean SQOL-F scale score of women who were breastfeeding was higher than those who were not breastfeeding, and the difference was significant (Table 2). There are also studies showing that breastfeeding leads to an increase in sexual desire and eroticism due to breast stimulation, increased sensitivity, increased breast size (Abdool et al., 2009; Avery, Duckett, \& Frantzich, 2000). Another study found that breastfeeding women returned to their pre-pregnancy sexual activity earlier (Rowland, Foxcroft, Hopman, \& Patel, 2005). It is stated that orgasm can increase with the natural effect of oxytocin (Convery \& Spatz, 2009; Johnson, 2012). In their study, La Marre et al. indicated that breastfeeding in some women may have a sexual satisfactory effect, which can lead to a decrease in sexual functions in women by creating a feeling of guilt (La Marre, Peterson, \& Gorzalka, 2003). In the present study, the mean SQOL-F scale score was found to be more positive in women who were breastfeeding their babies (Table 2). When the results of the research are evaluated, it is seen that there are findings that both support and oppose the results. This situation may be related to the woman's body perception and the quality of her relationship with her spouse during the postpartum period.

When the mean SQOL-F scale scores were evaluated according to women's of their physical appearance in the postpartum period, it was found that the mean SQOL-F scale score of women who evaluated their physical appearance as good was significantly higher than those who evaluated their physical appearance as average and poor (Table 2). Olsson et al. stated that mothers experienced many changes related to body image during the postpartum period and had difficulty dealing with these changes (Olsson, Lundqvist, Faxelid, \& Nissen, 2005).

Low body perception causes women to feel less attractive and display sexual intercourse avoidance behavior (Öz, 2010). When the SQOL-F scale scores were examined, it was thought that body image was one of the parameters affecting sex life.

When the SQL-F scores according to the characteristics of women's sexual life history were analyzed, the mean score of women; who had a frequency of five or more postpartum 
sexual intercourse per month, who evaluated their postpartum sexual life as good, and who were satisfied with postpartum spousal communication was high and the difference was found significant (Table 3). As a result of the study, satisfaction with the relationship with the spouse and the starting and continuation of sexual activity can be considered as a factor that increases the sharing of spouses and positively affects the quality of sexual intercourse.

When sexual problem areas were examined, women who reported decreased sexual desire, painful orgasm, feeling of vaginal laxity, decrease in vaginal lubrication, and difficulty in orgasm obtained a low mean score from the SQOL-F scale, and the difference was found to be significant (Table 3). In their study, Acele and Karaçam determined that $91.3 \%$ of women had sexual problems in the postpartum period and that $24.5 \%$ of them experienced a decrease in sexual desire (Acele \& Karaçam, 2011). The studies conducted in our country show that the majority of women experience dysparanoia and other sexual problems in the postpartum period (Acele \& Karaçam, 2011; Karaçam, 2008; Karaçam \& Çalışır, 2012). In our country, there are many studies stating that sexual dysfunctions are prevalent in married couples (Demir, Parlakay, Gök, \& Esen 2007; Ege, Akın, Yaralı, Arslan, \& Bilgili, 2010; İncesu, 2004; Öksüz \& Malhan, 2005). It was concluded that it would be helpful to give every woman who applied to healthcare institutions the opportunity to explain their sexual life and problems by being encouraged by health professionals.

According to realized logistic regression analysis, the variables that have a significant effect on the sexual life quality score of women -in order of importance- are as follows; postpartum sexual life assessment status, age, postpartum partner communication, vaginal dryness while sexual intercourse, decrease in sexual desire, frequency of sexual intercourse and employment status ( $\mathrm{p}<0.05$ ).

When factors that may pose a risk in terms of postpartum sexual quality of life were evaluated, it was observed that women who evaluated their postpartum sex life as poor, who were dissatisfied with their communication with their spouse, who had low sexual intercourse frequency, and who did not work experienced more problems. When all the results were evaluated, it was concluded that early detection of problems related to postpartum sexual life and the monitoring of women during pregnancy and the postpartum period were important.

\section{Conclusions}

According to the study results, it was seen that the postpartum period had a negative effect on the sexual life quality. It is recommended that health professionals should make use of the screening scales determining the problems of women and their spouses during the 
postpartum period. Beside this, especially women at high risk of experiencing sexual problems should be given priority by healthcare professionals, and planning of counseling services for all women before pregnancy, during pregnancy and in the postpartum period in order to protect and improve the sexual quality of life can be suggested. Moreover, realizing experimental designs for the management of risk factors that may affect the sexual life quality can be recommended.

\section{REFERENCES}

Abdool, Z., Thakar, R., Sultan, A. H. (2009). Postpartum female sexual function. European Journal of Obstetric \&Genecology and Reproductive Biology, 145(2), 133-137.

Acele, E.Ö., Karaçam, Z. (2011). Sexual problems in women during the first postpartum year and related conditions. Journal of Clinical Nursing, 21(7-8), 929-937.

Altuntuğ, K., Ege, E. (2012). Doğum sonu yaşam kalitesi ölçeğinin Türkçe uygulamasının geçerlilik ve güvenirliliği. Anadolu Hemşirelik ve Să̆lık Bilimleri Dergisi, 15(3), 214-222.

Avery, M.D., Duckett, L., Frantzich C.R. (2000). The Experience of sexuality during breastfeeding among primiparous women. Journal of Midwifery \& Women's Health, 45(3), 227-237.

Barrett, G., Pendry, E., Peacock, J., Victor, C., Thakar, R., Manyonda, I. (2000). Women's sexual health after birth. BJOG: International Journal of Obstetrics and Gynecology, 107, 186-195.

Basson, R., Brotto, L. A., Laan, E., Redmond, G., Utian, W.H. (2005). Kadının cinsel işlev bozukluklarının değerlendirilmesi ve yönetimi: Sorunlu arzu ve uyarllma. Cinsel Tip Dergisi, 2, 291-300.

Baytur, Y., Deveci, A., Uyar, Y., Özcakir, H., Kızılkaya, S., Çağlar, H. (2005). Doğumdan sonra doğum şekli ve pelvik taban kas gücü ve cinsel işlev. Uluslararası Jinekoloji ve Obstetrik Dergisi, 88, 276-280.

Brotto, L.A., Chik, H. M., Ryder, A.G., Gorzalka, B.B., Broke, N.S. (2006). Culturalization and sexual function in asian women. Arch Sex Behav, 34, 613-626.

Brubaker, L., Handa, V. L., Bradley, C.S., Connolly, A., Moalli, P., Brown, M.B., Weber, A. (2008). Sexual function 6 months after first delivery. Obstetrics and Gynecology, 111(5), 1040-1044.

Convery, KM., Spatz, DL. (2009). Sexuality breastfeeding: What do you know? MCN: The American Journal of Maternal/Child Nursing, 34(4), 218-223.

Demir, Ö., Parlakay, N., Gök, G., Esen, A.A. (2007). Hastane çalışanı bayanlarda cinsel işlev bozukluğu. Türk Üroloji Dergisi, 33, 156-160.

Demirci, N. (2012). Kadının yaşam dönemlerinde cinsellik ve cinsel sağllk. Coşkun A, Editör (2012). Kadın Sağlı̆̆ı ve Hastalıkları El Kitabı. İstanbul: Koç Üniversitesi Yayınları.

Ege, E., Akın, B., Yaralı, Arslan, S., Bilgili, N. (2010). Să̆lıklı kadınlarda cinsel fonksiyon bozukluğu sıklığı ve risk faktörleri. TÜBAV Bilim Dergisi, 3, 137-144.

Eshghi, R., Bahrami, F., Fatehi Zade, M., Etemadi, O., Ghasemi, V. (2012). The prediction of sexual function based on cognitive-emotional factors in Iranian women. Interdisciplinary JCRB, 4, 53-60.

Güngör, S., Başer, B., Ceyhan, S., Karaşahin, E., Acikel, C.H. (2007). Mode of delivery and subsequent longterm sexual function of S primiparous women. Int J Impot Res, 19, 358-365.

Incesu, C. (2004). Cinsel işlevler ve cinsel işlev bozuklukları. Klinik Psikiyatri Dergisi, 7, 3-13. 
Johnson, J.Y. (2012). Anne yenidoğan hemşireliği açıklı̆ga kavuşturulmuş kendi kendine öğrenim rehberi. (N. Çiçek ve L. Taşkın, Çev.). Ankara: Palme Yayıncılık.

Karaçam, Z. (2008). Normal postpartum dönem fizyolojisi ve bakımı. Editör: Şirin, A. ve Kavlak, O. Infertilite. İstanbul.

Karaçam, Z., Çalışır, H. (2012). Illk kez doğum yapan kadınlarda gebelik öncesi ve doğum sonrası dönemlerde disparoni sıklığı ve ilişkili durumlar. Anadolu Hemşirelik ve Sağlık Bilimleri Dergisi, 15(3), 205-213.

Klein, K., Worda, C., Leipold, H., Gruber, C., Husslein, P., Wenzl, R. (2009). Does the mode of delivery influence sexual function after childbirth? Journal of Women's Health, 18(8), 1227-31.

Koç, E., Oskay, Ü. (2016). Postpartum dönemde cinsellik ve danışmanlık. Kadın Sağlı̆̆ Hemşireliği Dergisi, $2(1), 15-26$.

Kurtçu, A., Gölbaşı, Z. (2014). Doğum sonrası depresyon: Birinci basamak să̆lık merkezlerinde çalışan hemşire ve ebelerin bilgi ve görüşleri. Fırat Üniversitesi Sağllk Bilimleri Tip Dergisi, 28(3), 93-99.

La Marre, A.K., Peterson, L.Q., Gorzalka, B.B. (2003). Breastfeeding and postpartum maternal sexual functioning: A review. The Canadian Journal of Human Sexuality, 12 (3- 4), 151-165.

Lurie, S., Aizenberg, M., Sulema, V., Boaz, M., Kovo, M., Golan, A., Sadan, O. (2013). Sexual function after childbirth by the mode of delivery: A prospective study. Arch Gynecol Obstet, 288(4),785-92.

Mert, D.G., Özen, N.E. (2011). Genel psikiyatri polikliniğine başvuran kadın hastalarda cinsel işlev bozukluğu ve ilişkili sosyokültürel parametrelerin değerlendirilmesi. Klinik Psikiyatri Dergisi, 14, 85-93.

Olsson, A., Lundqvist, M., Faxelid, E., Nissen, E. (2005). Women's thoughts on sexual life after birth: Focus group discussions with women after birth. Scandinavian Journal of Care Sciences, 19, 381-387.

Öksüz, E., Malhan, S. (2005). Să̆llğa bă̆ll yaşam kalitesi kalitemetri. Ankara: Başkent Üniversitesi.

Öz F. (2010). Să̆lık alanında temel kavramlar. Ankara: Mattek Matbaacılık.

Rathfisch, G., Dikencik, B.K., Klzılkaya, Beji, N., Comert, N., Tekirdă̆, A.L ve Kadıoğlu, A. (2010). Effects of perineal trauma on postpartum sexual function. Advanced Nursing Journal, 66, 2640-2649.

Rowland, M., Foxcroft, L., Hopman, W.M., Patel, R. (2005). Breastfeeding and sexuality immediately postpartum. Canadian Family Physician, 51(10), 1366-1367.

Serati, M., Salvatore, S., Siesto, G., Cattoni, E., Zanirato, M., Khullar, V.,...Bolis, P. (2010). Function during the female sexual pregnancy and postpartum. Journal of Sexual Medicine, 7, 2782-2790.

Signorello, L.B., Harlow, B.L., Chekos, A.K., Repke, J.T. (2001). Postpartum sexual functioning and its relationship to perineal trauma: A retrospective cohort study of primiparous women. Am J Obstet Gynecol, 184 (5), 881-890.

Symonds T, Boolell M, Quirk F. (2005). Development of questionnaire on sexual quality of life in women. J Sex Marital Ther, 31, 385-97.

Şahin, N. (2009). Kadınlarda postpartum dönemde cinsel yaşam. Zeynep Kamil Tıp Bülteni, 40 (3), $125-$ 130.

Trutnovsky, G., Haas, H., Long, U., Petru, E. (2006). Women's perception of sexuality during pregnancy and after birth. Australian and New Zealand Journal of Obstetrics and Gynaegology, 46, 282-287.

Tuğut, N, Gölbaşı, Z. (2010). Cinsel yaşam kalitesi ölçeği - Kadın Türkçe versiyonunun geçerlik ve güvenirlik çalışmast. Cumhuriyet Medical Journal, 32 (2), 172-180. 
Wang, H., Xu, X., Yao, Z., Zhou, Q. (2003). Impact of delivery types on women's postpartum sexual health. Reproduction Contraception, 14(4), 237-242

World Health Organization (WHO). Developing Sexual Health Programmes. 02 Şubat 2014 tarihinde http://www.who.International/reproductive health/gender/sexual health. html adresinden erişildi.

World Helath Organization Quality of Life Group (1998). Development of the World Health Organization WHOQOL- BREF Quality of Life Assessment. Pyschological Medicine, 28 (3), 551-558.

Yaralı, S., Hacıalioğlu, N. (2016). Evli kadınlarda cinsel fonksiyon bozukluğu ve cinsel yaşam kalitesinin incelenmesi. Uluslararası hakemli Hemşirelik Araştırmaları Dergisi, 2(1),108-127. 